\title{
Phylogenetic analysis of Peri-Mediterranean blennies of the genus Salaria: Molecular insights on the colonization of freshwaters
}

\author{
V.C. Almada ${ }^{\mathrm{a}}$, J.I. Robalo ${ }^{\mathrm{a}, *}$, A. Levy ${ }^{\mathrm{a}}$, J. Freyhof ${ }^{\mathrm{b}}$, G. Bernardi ${ }^{\mathrm{c}}$, I. Doadrio ${ }^{\mathrm{d}}$ \\ ${ }^{a}$ Unidade de Investigação em Eco-Etologia, Instituto Superior de Psicologia Aplicada. Rua Jardim do Tabaco 34, 1149-041 Lisboa, Portugal \\ ${ }^{\mathrm{b}}$ Leibniz - Institute of Freshwater Ecology and Inland Fisheries, Müggelseedamm 310, 12587 Berlin, Germany \\ ${ }^{\mathrm{c}}$ Department of Ecology and Evolutionary Biology, Long Marine Lab, University of California Santa Cruz, 100 Shaffer Road, Santa Cruz, CA 95060, USA \\ ${ }^{\mathrm{d}}$ Museo Nacional de Ciencias Naturales. CSIC. José Gutiérrez Abascal 2. 28006 Madrid, Spain
}

\section{A R T I C L E I N F O}

\section{Article history}

Received 18 November 2008

Revised 19 March 2009

Accepted 25 March 2009

Available online 5 April 2009

\section{Keywords:}

Salaria fluviatilis

Salaria pavo

Molecular clock

12s rRNA gene

16sRNA gene

Mitochondrial control region

S7 ribosomal protein gene

\begin{abstract}
A B S T R A C T
In this paper, the phylogenetic relationships of the marine blenny Salaria pavo and the freshwater S. fluviatilis and S. economidisi were analyzed using four molecular markers: the mitochondrial 12S rRNA, 16S rRNA, and the control region and the nuclear first intron of the S7 ribosomal protein. The monophyly of Salaria is supported, as well as that of $S$. pavo and that of all the freshwater members of Salaria. Thus, the present results support a single origin for all freshwater Mediterranean blenniids. Our results reject the placement of the species of Salaria in the genus Lipophrys as proposed in previous studies. Using a molecular clock calibrated with trans-Isthmian geminate blenniid species, the split between the ancestor of the freshwater lineage and the ancestor of $S$. pavo is tentatively placed in the Middle Miocene (well before the Messinian). The marine $S$. pavo displays a very low level of intraspecific sequence divergence consistent with a Pleistocene bottleneck. S. fluviatilis is a paraphyletic entity with S. economidisi nested within it. A Moroccan population of S. fluviatilis is more divergent than S. economidisi, both in nuclear and mitochondrial genes. Fish from Israel together with some Turkish samples represent the second oldest split. It is argued that these populations may represent cryptic species. Thus, further studies on the taxonomy of these freshwater blennies are urgently needed.
\end{abstract}

(c) 2009 Elsevier Inc. All rights reserved.

\section{Introduction}

The teleost fish family Blenniidae includes about 387 species which are typically small marine benthic fishes inhabiting hard inshore substrata of tropical and temperate waters (Nelson, 2006). Among these only three or four species occur in freshwater. In the Mediterranean region, Salaria fluviatilis (Asso, 1801) lives in rivers and lakes from Israel to the Iberian Peninsula, where it reaches some Atlantic rivers like the Guadiana. It is also present in Morocco, Algeria and many Mediterranean islands as Sardinia and Crete (e.g., Kottelat and Freyhof, 2007). Recently, Kottelat (2004) considered the population from lake Trichonis, in Greece, sufficiently distinct to be assigned to a new species Salaria economidisi (Kottelat, 2004). This finding raised the possibility that the widely distributed $S$. fluviatilis may be paraphyletic and that other cryptic species might be present within it.

Freshwater blennies of the genus Salaria have long been considered closely related to a marine inshore species, Salaria pavo (Risso, 1810) which also occurs around the Mediterranean, with a small extension in the adjacent Atlantic, from the bay of Biscay

\footnotetext{
* Corresponding author. Fax: +351 218860954

E-mail address: jrobalo@ispa.pt (J.I. Robalo).
}

south to the Canaries (Zander, 1986). Salaria pavo occurs both on rocky habitats and coastal lagoons, in the intertidal, or in the first meters of the subtidal. Another species of the genus, Salaria basilisca (Valenciennes, 1836), is rarely found and was described as living on sea grass beds, also within the Mediterranean (Heymer, 1985).

The taxonomic history of the Salaria species has been complex. They were merged for a long time in the genus Blennius (Norman, 1943), which included all north eastern Atlantic blenniids except for Coryphoblennius galerita (Linnaeus, 1758). This heterogeneous assemblage which encompassed more than 20 species was subsequently split, giving rise to several genera. Bath (1976), Almada et al. (2001), and Almada et al. (2005) argued for the validity of Salaria Forskål, 1775 (including S. fluviatilis, S. pavo and S. basilisca (Valenciennes, 1836)) although the last authors, using mitochondrial markers, could not confirm unequivocally the monophyly of the genus. Bock and Zander (1986) argued for the inclusion of Salaria in the genus Lipophrys Gill, 1896, a group of species morphologically very distinct and which currently comprises only $L$. pholis (Linnaeus, 1758) and L. trigloides (Valenciennes, 1836). For a review of the phylogeny of the north eastern Atlantic blenniids and its taxonomic implications see Almada et al. (2005). For the blenniids as a whole see (Almada et al., 2009). 
The morphological similarities between the Mediterranean freshwater blennies and S. pavo, and the observation that both $S$. pavo and $S$. fluviatilis can tolerate wide ranges of salinity (Plaut, 1998) led to a general acceptance that the freshwater members of Salaria, must have derived from S. pavo (Kosswig, 1967) or at least from a marine ancestor closely related to $S$. pavo (Zander, 1972; Perdices et al., 2000).

Perdices et al. (2000), using protein electrophoresis, found that there were greater differences between lake populations of $\mathrm{S}$. $\mathrm{flu}$ viatilis from Spain and Greece than those found between riverine populations from both countries. Thus, they raised the hypothesis that a marine ancestor could have given rise independently and at different times to several populations of $S$. fluviatilis. This possibility is also suggested by the almost parallel geographic distributions of $S$. pavo and S. fluviatilis.

In this paper, we used both mitochondrial and nuclear DNA from $S$. pavo samples collected from the Levantine Mediterranean to the Atlantic shores of Portugal, and samples of the freshwater Salaria ranging from Turkey to Portugal and Morocco, to address the following issues: (1) Is the inclusion of the species of Salaria in the genus Lipophrys supported by genetic evidence?; (2) Does Salaria form a monophyletic group?; (3) Are the freshwater blennies of the Mediterranean region a monophyletic group or do they represent independent instances of freshwater invasion by marine ancestors related to S. pavo?; (4) Do the colonisations of freshwaters correspond to a narrow time interval or did they take place at different periods?; (5) Is S. fluviatilis a sister species of the Greek $S$. economidisi or is it a paraphyletic entity requiring taxonomic revision?

\section{Material and methods}

\subsection{Sampling}

Samples of S. pavo were obtained from 34 individuals from 16 locations along the northern and eastern Mediterranean coast, including Mediterranean Islands, and along the Atlantic coast of the Iberian Peninsula. Thirty S. fluviatilis were sampled from 21 rivers or lakes in Israel, Turkey, Greece, Croatia, Morocco, and, with greater incidence, in the Iberian Peninsula. For collection site locations and GenBank Accession Numbers see Fig. 1 and Table 1. Except in the few cases when not enough biological material was available, all gene fragments were sequenced for each individual. In order to investigate the relationship between Salaria and Lipoprhys, the following species were also included in the analyses: Coryphoblennius galerita (Linnaeus, 1758), Lipophrys pholis (Linnaeus, 1758; type species of the genus Lipophrys), Parablennius ruber (Valenciennes, 1836), $P$. salensis Bath, 1990, and $P$. sanguinolentus (Pallas, 1814). Coryphoblennius galerita was shown in previous studies to belong to a well supported clade with the Lipophrys species (Almada et al., 2005) while the remaining taxa added tended to be closer to the species of Salaria (Almada et al., 2009). Salarias fasciatus (Bloch, 1786) was used as outgroup in all analysis because its Indo-Pacific distribution likely implies that it diverged from the remaining species, all with Atlanto-Mediterranean distributions, prior to the closure of the Tethys Sea (around 20 million years ago, Briggs, 1995).

\subsection{DNA extraction, amplification and sequencing}

Total genomic DNA was extracted from fin or muscle samples preserved in 96\% ethanol with the REDExtract-N-Amp kit (Sigma-Aldrich) following the manufacturers instructions. Voucher specimens are deposited in ISPA and MNCN collections (ethanol preserved tissues). PCR amplification of mitochondrial fragments and the first intron of the nuclear S7 ribosomal protein gene, were performed with the following pairs of primers: control region - L-Pro1 and H-DL1 (Ostellari et al., 1996); 12s rDNA - 12S For and 12SRev (Almada et al., 2005); 16s rDNA - 16SFor and 16SRev (Almada et al., 2005); and the first intron of the S7 ribosomal protein gene - S7RPEX1F and S7RPEX2R (Chow and Hazama, 1998). Further details on primers and PCR conditions are summarized in Supplementary material. For all genes, each sample was sequenced in both directions using the same PCR primers. Sequencing reactions were performed by Stabvida (Oeiras, Portugal; http://www.stabvida.com).

\subsection{DNA analysis}

All sequences were aligned using Clustal X (Thompson et al., 1997) and the alignment was deposited in TreeBase (http:// www.treebase.org, submission ID number: SN4366). Congruence among all data sets was tested by the incongruence-length difference test (ILD) (Farris et al., 1985), as implemented in Paup* v.4.0b10 (Swofford, 2003). ILD tests did not reveal significant heterogeneity neither among the mitochondrial markers $(p=0.85)$ nor between the combined mitochondrial data and the S7 intron $(p=0.57)$. Thus, all markers were combined and analyzed as a single data set. In addition, we also analyzed data sets including only the S7 nuclear region, a combined mitochondrial data set, and each mitochondrial fragment separately.

Maximum parsimony-based (MP) phylogenetic relationships were estimated using PAUP* with 100 heuristic searches using random additions of sequences and implementing the TBR algorithm. Support values for individual nodes was assessed using 1000 bootstrap resamplings (Felsenstein, 1985). We conducted phylogenetic analysis on each fragment separately, on a concatenated mitochon-

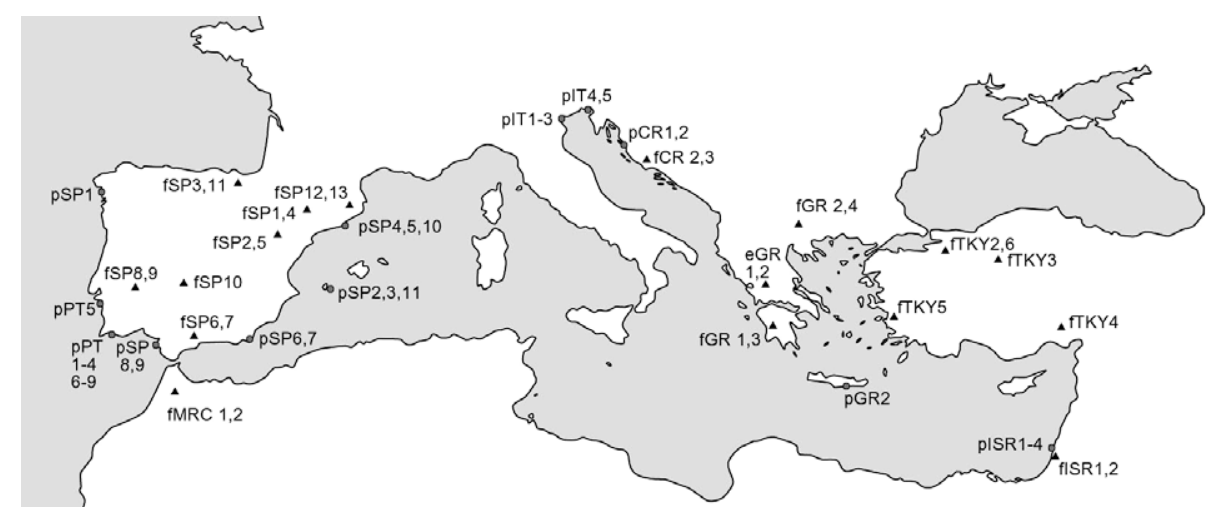

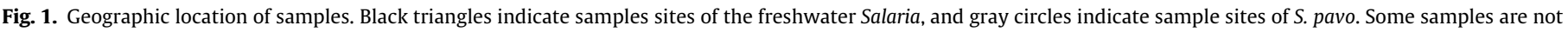
included in Fig. 2, but appear in the trees in Supplementary material. 
Table 1

Collection sites for the specimens used in this paper.

\begin{tabular}{|c|c|c|c|c|c|c|c|}
\hline \multirow[t]{2}{*}{ Species } & \multirow[t]{2}{*}{ Label } & \multicolumn{4}{|c|}{ GenBank Accession Numbers } & \multirow[t]{2}{*}{ Country } & \multirow[t]{2}{*}{ Locality, lake or river } \\
\hline & & $12 \mathrm{~s}$ & $16 \mathrm{~s}$ & dloop & s7 & & \\
\hline Salarias fasciatus & & NC_004412 & NC_004412 & NC_004412 & FJ465580 & & \\
\hline Parablennius sanguinolentus & & AF414700 & AY098837 & EF554671 & FJ465583 & & \\
\hline Parablennius ruber & & AF414716 & DQ160204 & AY098862 & FJ465582 & & \\
\hline Parablennius salensis & & AY098789 & AY098836 & AY098863 & FJ465581 & & \\
\hline Coryphoblennius galerita & & EF521800 & EF521665 & EF521746 & EF527784 & & \\
\hline Lipophrys pholis & & AY098765 & AY987019 & AY966019 & FJ465584 & Portugal & Azores \\
\hline Salaria pavo & $\begin{array}{l}\text { pIT1 } \\
\text { pIT2 } \\
\text { pIT3 } \\
\text { pIT4 } \\
\text { pIT5 } \\
\text { pGR1 } \\
\text { pGR2 } \\
\text { pPT1 } \\
\text { pPT2 } \\
\text { pPT3 } \\
\text { pPT4 } \\
\text { pPT5 } \\
\text { pPT6 } \\
\text { pPT7 } \\
\text { pPT8 } \\
\text { pPT9 } \\
\text { pSP1 } \\
\text { pSP2 } \\
\text { pSP3 } \\
\text { pSP4 } \\
\text { pSP5 } \\
\text { pSP6 } \\
\text { pSP7 } \\
\text { pSP8 } \\
\text { pSP9 } \\
\text { pSP10 } \\
\text { pSP11 } \\
\text { pISR1 } \\
\text { pISR2 } \\
\text { pISR3 } \\
\text { pISR4 } \\
\text { pCR1 } \\
\text { pCR2 }\end{array}$ & $\begin{array}{l}\text { AY098801 } \\
\text { FJ465672 } \\
\text { FJ465675 } \\
\text { FJ465679 } \\
\text { FJ465680 } \\
\text { AY098799 } \\
\text { FJ465668 } \\
\text { FJ465666 } \\
\text { FJ465667 } \\
\text { FJ465669 } \\
\text { FJ465670 } \\
\text { FJ465682 } \\
\\
\\
\text { FJ465671 } \\
\text { FJ465673 } \\
\text { FJ465676 } \\
\text { FJ465685 } \\
\text { FJ465697 } \\
\text { FJ465698 } \\
\text { FJ465699 } \\
\text { FJ465700 } \\
\text { FJ465701 } \\
\text { FJ465702 } \\
\text { FJ465674 } \\
\text { FJ465677 } \\
\text { FJ465678 } \\
\text { FJ465681 } \\
\text { FJ465692 } \\
\text { FJ465693 }\end{array}$ & $\begin{array}{l}\text { FJ465720 } \\
\text { FJ465719 } \\
\text { FJ465713 } \\
\text { FJ465714 } \\
\text { FJ465721 } \\
\text { FJ465717 } \\
\text { FJ465708 } \\
\text { FJ465712 } \\
\text { FJ465716 } \\
\text { FJ465711 } \\
\\
\\
\\
\text { FJ465715 } \\
\text { FJ465707 } \\
\text { FJ465709 } \\
\text { FJ465710 } \\
\text { FJ465750 } \\
\text { FJ465755 } \\
\text { FJ465751 } \\
\text { FJ465752 } \\
\text { FJ465753 } \\
\text { FJ465754 } \\
\text { FJ465705 } \\
\text { FJ465703 } \\
\text { FJ465706 } \\
\text { FJ465704 } \\
\text { FJ465749 }\end{array}$ & $\begin{array}{l}\text { FJ465558 } \\
\text { FJ465565 } \\
\text { FJ465561 } \\
\text { FJ465571 } \\
\text { FJ465559 } \\
\text { FJ465574 } \\
\text { FJ465573 } \\
\text { FJ465577 } \\
\\
\text { FJ465546 } \\
\text { FJ465544 } \\
\text { FJ465545 } \\
\text { FJ465547 } \\
\text { FJ465579 } \\
\text { FJ465562 } \\
\text { FJ465555 } \\
\text { FJ465572 } \\
\text { FJ465560 } \\
\text { FJ465576 } \\
\text { FJ465578 } \\
\text { FJ465575 } \\
\text { FJ465557 } \\
\text { FJ465554 } \\
\text { FJ465568 } \\
\text { FJ465563 } \\
\text { FJ465570 } \\
\text { FJ465569 } \\
\text { FJ465552 } \\
\text { FJ465553 }\end{array}$ & $\begin{array}{l}\text { FJ465618 } \\
\text { FJ465623 } \\
\text { FJ465632 } \\
\text { FJ465635 } \\
\text { FJ465619 } \\
\text { FJ465636 } \\
\text { FJ465628 } \\
\text { FJ465616 } \\
\\
\text { FJ465642 } \\
\text { FJ465639 } \\
\text { FJ465640 } \\
\text { FJ465641 } \\
\text { FJ465613 } \\
\text { FJ465624 } \\
\text { FJ465622 } \\
\text { FJ465614 } \\
\text { FJ465633 } \\
\text { FJ465629 } \\
\text { FJ465630 } \\
\text { FJ465631 } \\
\text { FJ465634 } \\
\text { FJ465617 } \\
\text { FJ465609 } \\
\text { FJ465626 } \\
\text { FJ465620 } \\
\text { FJ465627 } \\
\text { FJ465615 } \\
\text { FJ465608 }\end{array}$ & $\begin{array}{l}\text { Italy } \\
\text { Italy } \\
\text { Italy } \\
\text { Italy } \\
\text { Italy } \\
\text { Greece } \\
\text { Greece } \\
\text { Portugal } \\
\text { Portugal } \\
\text { Portugal } \\
\text { Portugal } \\
\text { Portugal } \\
\text { Portugal } \\
\text { Portugal } \\
\text { Portugal } \\
\text { Portugal } \\
\text { Spain } \\
\text { Spain } \\
\text { Spain } \\
\text { Spain } \\
\text { Spain } \\
\text { Spain } \\
\text { Spain } \\
\text { Spain } \\
\text { Spain } \\
\text { Spain } \\
\text { Spain } \\
\text { Israel } \\
\text { Israel } \\
\text { Israel } \\
\text { Israel } \\
\text { Croatia } \\
\text { Croatia }\end{array}$ & $\begin{array}{l}\text { Chioggia } \\
\text { Chioggia } \\
\text { Chioggia } \\
\text { Trieste } \\
\text { Trieste } \\
\text { Crete } \\
\text { Olhos de Água } \\
\text { Olhos de Água } \\
\text { Ria Formosa } \\
\text { Ria Formosa } \\
\text { Sado } \\
\text { Ria Formosa } \\
\text { Ria Formosa } \\
\text { Ria Formosa } \\
\text { Ria Formosa } \\
\text { Galiza } \\
\text { Formentera } \\
\text { Formentera } \\
\text { Barcelona } \\
\text { Barcelona } \\
\text { Cabo da Gata } \\
\text { Cabo da Gata } \\
\text { Cádiz } \\
\text { Cádiz } \\
\text { Barcelona } \\
\text { Formentera } \\
\end{array}$ \\
\hline Salaria fluviatilis & $\begin{array}{l}\text { fPT1 } \\
\text { fGR1 } \\
\text { fGR2 } \\
\text { fGR3 } \\
\text { fGR4 } \\
\text { fTRK1 } \\
\text { fTRK2 } \\
\text { fTRK3 } \\
\text { fTRK4 } \\
\text { fTRK5 } \\
\text { fTRK6 } \\
\text { fSP1 } \\
\text { fSP2 } \\
\text { fSP3 } \\
\text { fSP4 } \\
\text { fSP5 } \\
\text { fSP6 } \\
\text { fSP7 } \\
\text { fSP8 } \\
\text { fSP9 } \\
\text { fSP10 } \\
\text { fSP11 } \\
\text { fSP12 } \\
\text { fSP13 } \\
\text { fMRC1 } \\
\text { fMRC2 } \\
\text { fISR1 } \\
\text { fISR2 } \\
\text { fCR1 } \\
\text { fCR2 } \\
\text { fCR3 }\end{array}$ & $\begin{array}{l}\text { AY098797 } \\
\text { FJ465645 } \\
\text { FJ465646 } \\
\text { FJ465653 } \\
\text { FJ465656 } \\
\text { FJ465647 } \\
\text { FJ465657 } \\
\text { FJ465658 } \\
\text { FJ465659 } \\
\text { FJ465687 } \\
\\
\text { FJ465648 } \\
\text { FJ465649 } \\
\text { FJ465650 } \\
\text { FJ465651 } \\
\text { FJ465652 } \\
\text { FJ465654 } \\
\text { FJ465655 } \\
\text { FJ465660 } \\
\text { FJ465661 } \\
\text { FJ465662 } \\
\text { FJ465665 } \\
\text { FJ465690 } \\
\text { FJ465691 } \\
\text { FJ465663 } \\
\text { FJ465664 } \\
\text { FJ465683 } \\
\text { FJ465684 } \\
\text { FJ465686 } \\
\text { FJ465688 } \\
\text { FJ465689 }\end{array}$ & $\begin{array}{l}\text { AY098843 } \\
\text { FJ465725 } \\
\text { FJ465738 } \\
\text { FJ465729 } \\
\text { FJ465739 } \\
\text { FJ465742 } \\
\text { FJ465731 } \\
\text { FJ465727 } \\
\text { FJ465723 } \\
\\
\text { FJ465741 } \\
\text { FJ465744 } \\
\text { FJ465730 } \\
\text { FJ465745 } \\
\text { FJ465740 } \\
\text { FJ465724 } \\
\text { FJ465743 } \\
\text { FJ465734 } \\
\text { FJ465732 } \\
\text { FJ465728 } \\
\text { FJ465726 } \\
\text { FJ465747 } \\
\text { FJ465748 } \\
\text { FJ465736 } \\
\text { FJ465737 } \\
\text { FJ465718 } \\
\text { FJ465722 } \\
\text { FJ465746 }\end{array}$ & $\begin{array}{l}\text { AY098865 } \\
\text { FJ465542 } \\
\text { FJ465539 } \\
\text { FJ465538 } \\
\text { FJ465543 } \\
\text { FJ465535 } \\
\text { FJ465536 } \\
\text { FJ465537 } \\
\text { FJ465549 } \\
\text { FJ465534 } \\
\text { FJ465521 } \\
\text { FJ465533 } \\
\text { FJ465528 } \\
\text { FJ465532 } \\
\text { FJ465522 } \\
\text { FJ465529 } \\
\text { FJ465524 } \\
\text { FJ465525 } \\
\text { FJ465531 } \\
\text { FJ465530 } \\
\text { FJ465523 } \\
\text { FJ465556 } \\
\text { FJ465566 } \\
\text { FJ465527 } \\
\text { FJ465526 } \\
\text { FJ465567 } \\
\text { FJ465564 } \\
\text { FJ465548 } \\
\text { FJ465550 } \\
\text { FJ465551 }\end{array}$ & $\begin{array}{l}\text { FJ465597 } \\
\text { FJ465603 } \\
\text { FJ465598 } \\
\text { FJ465602 } \\
\text { FJ465610 } \\
\text { FJ465611 } \\
\text { FJ465585 } \\
\text { FJ465612 } \\
\text { FJ465604 } \\
\text { FJ465596 } \\
\text { FJ465594 } \\
\text { FJ465605 } \\
\text { FJ465595 } \\
\text { FJ465587 } \\
\text { FJ465586 } \\
\text { FJ465590 } \\
\text { FJ465589 } \\
\text { FJ465588 } \\
\text { FJ465593 } \\
\text { FJ465638 } \\
\text { FJ465637 } \\
\text { FJ465591 } \\
\text { FJ465592 } \\
\text { FJ465625 } \\
\text { FJ465621 } \\
\text { FJ465606 } \\
\text { FJ465607 }\end{array}$ & $\begin{array}{l}\text { Portugal } \\
\text { Greece } \\
\text { Greece } \\
\text { Greece } \\
\text { Greece } \\
\text { Turkey } \\
\text { Turkey } \\
\text { Turkey } \\
\text { Turkey } \\
\text { Turkey } \\
\text { Turkey } \\
\text { Spain } \\
\text { Spain } \\
\text { Spain } \\
\text { Spain } \\
\text { Spain } \\
\text { Spain } \\
\text { Spain } \\
\text { Spain } \\
\text { Spain } \\
\text { Spain } \\
\text { Spain } \\
\text { Spain } \\
\text { Spain } \\
\text { Morocco } \\
\text { Morocco } \\
\text { Israel } \\
\text { Israel } \\
\text { Croatia } \\
\text { Croatia } \\
\text { Croatia }\end{array}$ & $\begin{array}{l}\text { River Guadiana } \\
\text { River Miras } \\
\text { Lake Dojranis } \\
\text { River Miras } \\
\text { Lake Dojranis } \\
\text { River Dalaman } \\
\text { Lake Iznik } \\
\text { Ilica } \\
\text { River Çatk t } \\
\text { River Tahtal } \\
\text { Stream Çak rca } \\
\text { River Noguera-Pallaresa } \\
\text { River Matarraña } \\
\text { Lake Calahorra } \\
\text { River Noguera-Pallaresa } \\
\text { River Matarraña } \\
\text { River Verde } \\
\text { River Verde } \\
\text { River Zújar } \\
\text { River Zújar } \\
\text { River Esteras } \\
\text { Lake Calahorra } \\
\text { Lake Banõles } \\
\text { Lake Banõles } \\
\text { River Overrha } \\
\text { River Overrha }\end{array}$ \\
\hline
\end{tabular}


Table 1 (continued)

\begin{tabular}{|c|c|c|c|c|c|c|c|}
\hline \multirow[t]{2}{*}{ Species } & \multirow[t]{2}{*}{ Label } & \multicolumn{4}{|c|}{ GenBank Accession Numbers } & \multirow[t]{2}{*}{ Country } & \multirow[t]{2}{*}{ Locality, lake or river } \\
\hline & & $12 \mathrm{~s}$ & $16 \mathrm{~s}$ & dloop & s7 & & \\
\hline \multirow[t]{2}{*}{ Salaria economisidi } & eGR1 & FJ465643 & FJ465733 & FJ465540 & FJ465600/FJ465601 & Greece & Lake Trichonis \\
\hline & eGR2 & FJ465644 & FJ465735 & FJ465541 & FJ465599 & Greece & Lake Trichonis \\
\hline
\end{tabular}

drial alignment, and on an alignment including mitochondrial and nuclear regions.

Minimum-evolution (ME; Saitou and Nei, 1987) phylogenetic trees were inferred, in PAUP*, based on maximum likelihood distances, assuming, for each genetic fragment or combination of fragments, the evolutionary model selected using the AIC criteria, as implemented in ModelTest v3.7 (Posada and Crandall, 1998). Branch support was tested by bootstrap analysis, with 1000 resamplings. Maximum likelihood (ML) phylogenetic trees for the full dataset were inferred in PAUP*, based on the evolutionary models selected by ModelTest. Branch support was tested by bootstrap analysis, with 100 resamplings.

Bayesian analysis (BY), using MRBAYES 3.1.2 (Huelsenbeck and Ronquist, 2001; Ronquist and Huelsenbeck, 2003), was performed on a concatenated mitochondrial alignment, setting independent partitions for each fragment and allowing independent GTR $+\Gamma+\mathrm{I}$ models of nucleotide evolution to be applied to each partition. Two analyses of four simultaneous MCMC chains were run for 7 million generations each (sampling parameters every 1000 generations), with the heating parameter set to 0.1. Two similar analyses using only the S7 region were run for 4 million generations (sampling parameters every 100 generations), and two analyses using all fragments combined, each with an independent GTR $+\Gamma+$ I model, for 2 million generations (sampling parameters every 100 generations). In all cases, the average standard deviation of split frequencies indicated convergence among independent runs. Majority-rule consensus trees were estimated combining results from duplicated analyses, after discarding the first 2000 samples.

To investigate the support for a relationship between the Lipophrys - Coryphoblennius species pair and Salaria, we compared topologies obtained from unconstrained trees with results from phylogenetic inference where Lipophrys - Coryphoblennius and all the species of Salaria were constrained to form a monophyletic group, under the parsimony criterion - using a Wilcoxon signedrank (Templeton, 1983) and Kishino-Hasegawa (K-H; Kishino and Hasegawa, 1989) tests - and, under the likelihood criterion-using Shimodaira-Hasegawa (S-H; Shimodaira and Hasegawa, 1999) and $\mathrm{K}-\mathrm{H}$ tests to compare constrained and unconstrained ME topologies - as implemented in PAUP*. Tests were performed on the combined mitochondrial and nuclear data set. The same procedures were applied to test the monophyly of Salaria.

We computed net genetic distances among species and groups of samples, using the model selected by ModelTest and correcting them by subtracting the average within-group distances from the average inter-group distances.

To examine whether the data set of each genetic region evolved at equal rates (strict molecular clock), we conducted a likelihood ratio test comparing topologies obtained with and without a molecular clock constraint, using PAUP*. We used a calibration of the molecular clock specific for each genetic fragment, based on the mean net percent divergence between Hypsoblennius invemar (from the Gulf of Mexico, Texas) and Hypsoblennius brevipinnis (from the Pacific coast of Panama), assuming they diverged before the formation of the Isthmus of Panama (circa 3.5 MYA). Average net genetic distances between groups of samples, obtained using the evolutionary model inferred by ModelTest, were converted into divergence times for those genetic fragments that did not reject the strict molecular clock hypothesis. Divergence times were also estimated, for these fragments, in a Bayesian framework, using BEAST v1.4.7 (Drummond and Rambaut, 2007), assuming a fixed substitution rate, a GTR $+\Gamma$ substitution model with 6 gamma categories, a Yule process prior, and - given the results of our phylogenetic analysis - assuming the monophyly of each Salaria species. Each such analysis was run for 10 million generations, sampling every 1000 generations, and discarding the first $10 \%$ of samples.

\section{Results}

The mitochondrial data set consisted of a total of 1512 characters (433, 604 and 475 bp for $12 \mathrm{~S}, 16 \mathrm{~S}$ and control region, respectively), including 445 parsimony informative sites and 857 invariant sites, whereas the S7 nuclear region consisted of 743 characters, including 194 parsimony informative sites and 355 invariant sites. No indication of saturation was found when plotting transitions and transversions versus uncorrected $p$ distances (data not shown). The results of the phylogenetic analyses for the entire data set are presented in Fig. 2. The results for the mitochondrial and nuclear data sets are presented as Supplementary material. For the entire data set, 1260 equally parsimonious trees of 2032 steps were obtained. Regardless of data set, no inference method yielded trees in which the Salaria species were recovered with $L$. pholis and $C$. galerita. These two species were consistently recovered in the same clade. When the consensus MP tree was compared with the one in which L. pholis, C. galerita and all members of Salaria were constrained to form a monophyletic group the difference was not significant (Templeton test: $p=0.064$; $\mathrm{K}-\mathrm{H}$ test: $p=0.066$ ). However, the constrained ME tree had a significantly lower likelihood than the unconstrained one $(\mathrm{S}-\mathrm{H}: \mathrm{p}<0.0001$; $\mathrm{K}-\mathrm{H}: p<0.0001)$. On the contrary, analysis of the full data set for MP and BY analysis (see Fig. 2), MP analysis of the mitochondrial data and ME and BY analysis of the S7 region (see Supplementary material), indicated a closer relationship between Salaria and Parablennius.

The ME and BY analysis of the full data set supported the monophyly of the genus Salaria (see Fig. 2). Although MP failed to recover this monophyly (Fig. 2), there was no significant difference between the unconstrained tree and one in which the monophyly of Salaria was enforced (Templeton test: $p=0.80$; $\mathrm{K}-\mathrm{H}$ test: $p=0.80$ ). MP, ME and BY, when applied to the S7 region (see Supplementary material) also supported the monophyly of Salaria. All phylogenetic analyses, regardless of inference method, strongly supported the monophyly of both $S$. pavo and that of the freshwater blennies. This result was recovered with all inference methods using each genetic marker separately, combining all mitochondrial markers, and combining mitochondrial and nuclear markers. The freshwater blenny clade revealed greater substructure than S. pavo. All genetic markers and combinations of markers identified a well supported basal Moroccan clade that differed greatly from the remaining freshwater Salaria (average net genetic distance of concatenated mitochondrial markers between this clade and the remaining freshwater Salaria: 0.054; the corresponding value for S7 was 0.023 ). The next most basal clade, which also appeared recurrently in all analyses with significant support, comprised sequences from Israel and some from Turkey. Sister to this clade was a heterogeneous group of fish widespread across the Mediterranean. Within this group, S. economidisi (Lake Trichonis) emerged as sister to a clade comprising the samples from the Iberian Peninsula, Croatia, Greece and a few Turkish samples. 


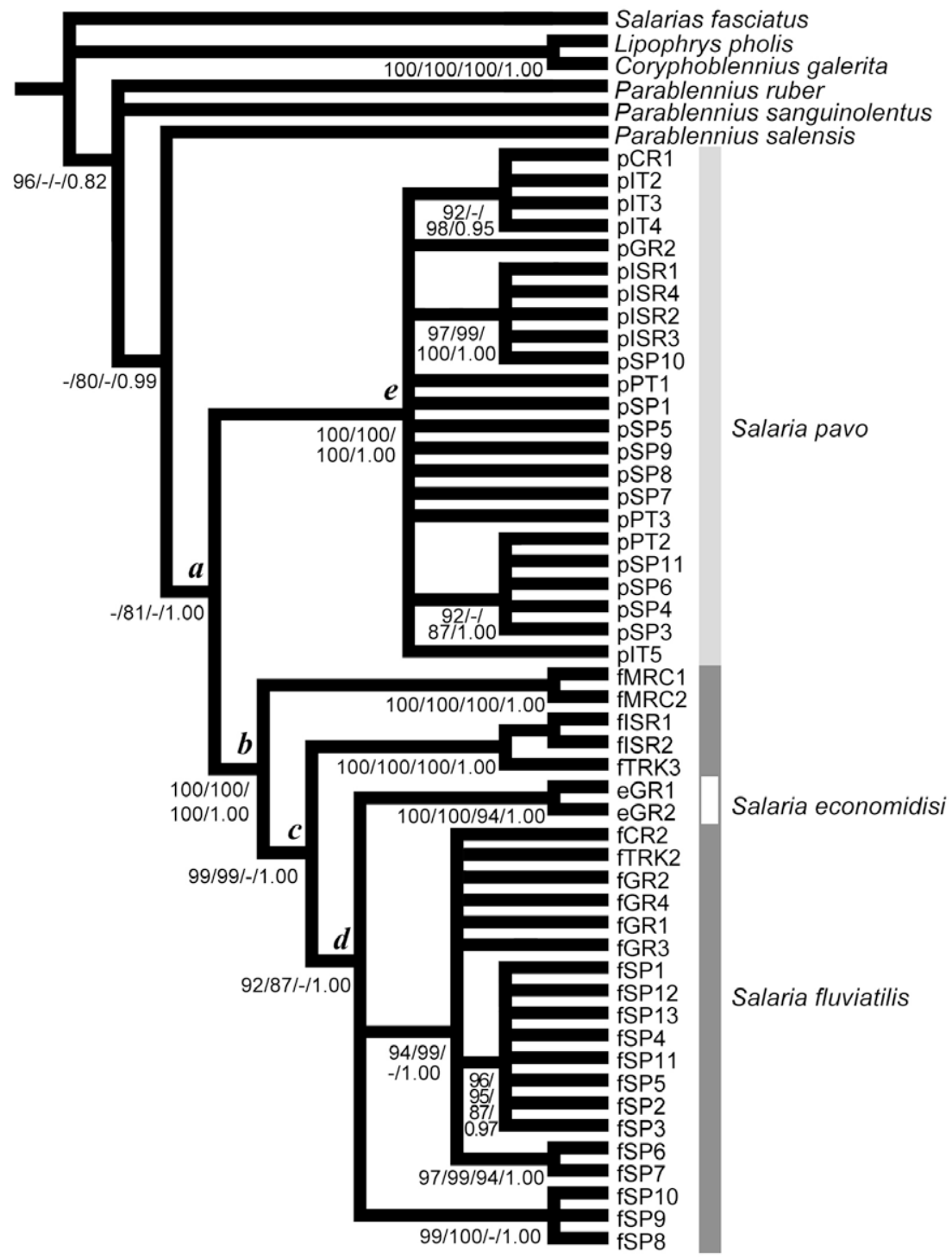

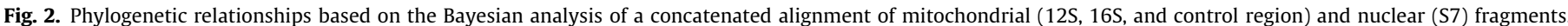

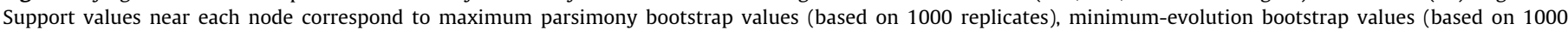

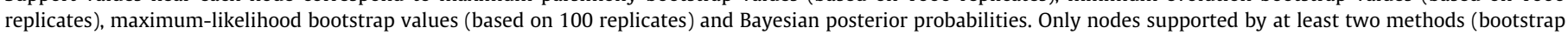
greater than $75 \%$; posterior probability greater than 0.8 ) are illustrated.

Overall, we found little geographic structure among samples of S. pavo. The presence of fish from Israel and Spain in the same clade (Fig. 2) indicates either the persistence of an ancient polymorphism, or a high level of gene flow throughout the Mediterranean.

The genetic distance among sequences was lower within S. pavo than within freshwater Salaria (average genetic distance of concatenated mitochondrial markers: 0.016 (range $0.00-0.038$ ) and 0.068 (range 0.00-0.630), respectively. The corresponding figures for S7 were $0.002(0.00-0.010)$ and $0.005(0.00-0.029)$, respectively. The distance between S. pavo and the freshwater clade was an order of magnitude greater than the distances within each of these clades (average net distance were 0.332 for the concatenated mitochondrial markers and 0.120 for S7, respectively). The estimated times of divergence for the major splits in our tree are presented in Fig. 2 and summarized in Table 2. These times were obtained using only the $12 \mathrm{~S}$ and $16 \mathrm{~S}$ fragments because the strict molecular clock hypothesis was rejected for the control region and S7 intron. A striking feature of these results is the very sharp discrepancy between the time estimated for the divergence of $S$. pavo and the freshwater Salaria, and the average divergence within S. pavo. The intra-specific divergence in S. pavo, particularly in the $12 \mathrm{~S}$ fragment, is so small that almost a single haplotype was found across its distribution, which suggests that a major bottleneck may have occurred in the recent history of this species. This low divergence means that we may be overestimating the net divergence time in comparisons which involve S. pavo and the freshwater blennies.

\section{Discussion}

Our results clearly reject the inclusion of the species of Salaria in the genus Lypophrys, as proposed by Bock and Zander (1986) and Zander (1986). This finding had already been suggested based on mitochondrial data only, by Almada et al. (2005). The latter authors suggested that the species of Salaria were more closely related to species of Parablennius and Scartella than to Lipophrys. Although Scartella was not included in the present study, the affinity between the species of Salaria and Parablennius was supported, although further studies including more taxa are needed to con- 
Table 2

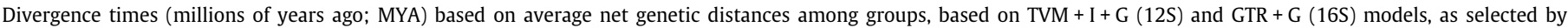

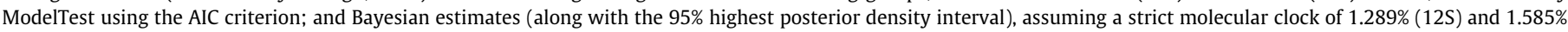
sequence divergence/MY (16S). Letters refer to nodes in Fig. 2.

\begin{tabular}{|c|c|c|c|c|c|}
\hline & & \multicolumn{2}{|c|}{ Divergence times } & \multicolumn{2}{|l|}{ Bayesian estimates } \\
\hline & & $12 \mathrm{~S}$ & $16 S$ & $12 \mathrm{~S}$ & $16 S$ \\
\hline a. & The most recent common ancestor (mrca) of Salaria & 20.50 & 12.85 & $12.74[10.28-15.10]$ & $7.99[5.60-10.43]$ \\
\hline b. & mrca of the freshwater clade & 3.96 & 3.86 & $3.23[2.17-4.32]$ & $2.80[1.93-3.68]$ \\
\hline c. & mrca of the Israeli-Turkish clade & 1.26 & 1.04 & $1.86[1.19-2.57]$ & $1.47[0.93-2.09]$ \\
\hline d. & mrca of S. economidisi & 1.45 & 0.92 & $1.86[1.19-2.37]$ & $0.94[0.55-1.33]$ \\
\hline e. & mrca of S. pavo & 0.01 & 0.52 & $0.93[0.53-1.39]$ & $1.14[0.70-1.63]$ \\
\hline
\end{tabular}

firm this conclusion. Interestingly, members of Salaria, Scartella and Parablennius share a number of morphological similarities like the prevalence of 14 rays in the pectoral fins, presence of supraorbital tentacles and glands on the two anal spines in males. On the contrary, Lipophrys, Coryphoblennius and their close relatives Microlipophrys typically present 12 rays on the pectorals and lack supra-orbital tentacles and anal glands (Bath, 1976; Almada et al., 2005).

Our results point to the monophyly of Salaria. Almada et al. (2005), in a phylogenetic study of the north eastern Atlantic and Mediterranean blenniids, were unable to recover Salaria as a clade. Their results were, however, based on fragments of the mitochondrial ribosomal genes only. In the present study, the inclusion of the control region and S7 allowed the recovery of the monophyly of the genus for the entire data set, as well as for the control region and S7 when analyzed separately. Unfortunately, the authors were unable to get sequences of $S$. basilisca. Despite of intensive efforts and contacts with museums and ichthyologists working in the Mediterranean, no tissues samples adequate for genetic analysis could be found and apparently the species has not been collected in recent years. It is known to be a close relative of $S$. pavo, that inhabits eelgrass beds and which hybridizes naturally with $S$. pavo (Heymer, 1985). Because the type species of Salaria is S. basilisca, its absence from the present analysis precludes drawing definitive conclusions on the phylogeny of Salaria. However, the present paper clearly demonstrates that all the freshwater blenniids of the Mediterranean region and the marine $S$. pavo derived from a common ancestor.

A clear result of the present study is the strong evidence supporting the monophyly of $S$. pavo on one hand, and that of the freshwater forms of Salaria, on the other. All markers supported this conclusion. Furthermore, the distance between the two clades is much larger than the distances within each group, suggesting that the split between $S$. pavo and the freshwater lineage occurred well before the diversification of the present day populations. Thus, the hypothesis suggested by Kosswig (1967) that S. fluviatilis could be a polytypic entity formed by multiple invasions of freshwater by S. pavo is not supported. The hypothesis of Perdices et al. (2000) differs from that of Kosswig in that the presumed ancestor of the freshwater blennies was not $S$. pavo, but a closely related marine species that would have become extinct. In any event, it is not parsimonious to assume that the ancestor of all freshwater blennies kept its saltwater preferences after splitting from S. pavo, colonizing multiple freshwater systems and becoming extinct in the sea. Thus, although the available evidence is not conclusive, we consider that a single evolutionary step from a marine form to one capable of living and breeding in brackish and freshwater is more parsimonious. This situation contrasts with that found in sticklebacks Gasterosteus aculeatus Linnaeus, 1758 complex, where freshwater populations resulted from multiple invasions from the sea (Bell and Foster, 1994). In sticklebacks, however, many individuals display active migratory behavior and move between the sea and freshwater habitats, a feature that likely facilitated the establish- ment of permanent freshwater populations. Blenniids, on the contrary, are benthic sedentary fish that after settlement display restricted movements and tend to stay near stones, boulders and other shelters.

The within-clade distances were much higher in the freshwater blennies than in S. pavo. This finding, although surprising at first, is to be expected, considering that the freshwater populations became isolated, increasing the likelihood that drift led different alleles to fixation in different populations, helping to preserve an overall higher level of genetic diversity (Avise, 2000). In any case, as it was already stated, the intra-specific divergence values in S. pavo are extremely low, raising the possibility of a very severe bottleneck. Salaria pavo is a fish with high thermal preferences and laboratory studies showed that development of the embryos is arrested at temperatures of $15^{\circ} \mathrm{C}$ or lower (Westernhagen, 1983). Hayes et al. (2005) estimated that western Mediterranean sea surface temperatures in the last glacial maximum ranged from about $9{ }^{\circ} \mathrm{C}$ in winter to $13^{\circ} \mathrm{C}$ in summer. These values mean that temperatures suitable for the reproduction of $S$. pavo were likely absent, in much of the Mediterranean. As the paleotemperatures of the north eastern Atlantic along the Iberian coast were even more severe during glacial periods (Dias et al., 1997; Loncaric et al., 1998) it is very likely that this species must have been extirpated from the Atlantic, surviving only in the warmer parts of the Mediterranean. Moreover, S. pavo occurs in a spectrum of habitats that are more restricted than those used by other Mediterranean blenniids. It requires reduced wave action and is often found in places with freshwater runoff (Zander, 1972). These restrictive habitat preferences may have aggravated the situation of the species during cold periods, when compared to other blenniids, as many of the rocky habitats available in the warmer refugia would not be suitable for $S$. pavo.

It could be argued that the reduced variation of $S$. pavo across its distribution may have resulted from high gene flow, instead of a bottleneck. High gene flow would explain the lack of a geographic pattern of variation but it would be more difficult to explain the paucity of haplotypes found in the species as a whole. Without a bottleneck, it is hard to conceive a population spread across the entire Mediterranean and adjacent Atlantic with such a small number of distinct haplotypes. Studies on the phylogeography and historical demography of $S$. pavo are needed to test this hypothesis.

The very low divergence observed in S. pavo implies that any attempt to apply a molecular clock to the present data must be subjected to a substantial level of uncertainty. Another caveat refers to the use of the timing of the formation of the Isthmus of Panama to calibrate the molecular clock. Indeed, rocky habitats and fully marine conditions may have ceased to exist considerably earlier than the final completion of the isthmus, which means that we may be underestimating the actual divergence times. Moreover, there is no publish phylogeny of the genus Hypsoblennius which implies that we can not be sure that $H$. invemar and $H$. brevipinnis are true sister species. This possibility also means that the divergence between the two Hypsoblennius species may be much older than 
the most recent rising of the isthmus. Unfortunately, there are no other species pairs of blenniids distributed on both sides of the isthmus to undertake a more accurate calibration. Muss et al. (2001) compared the cytochrome $b$ of species of Ophioblennius, a genus that occurs in the tropical Atantic and the eastern tropical Pacific. They found that even the divergence among different Atlantic populations started well before the separation of the two oceans. In view of this, these authors adopted the calibration of Bermingham et al. (1997), which is not specific for blenniids and was only based on comparisons of the cytochrome oxidase gene. Judging from the figures in Table 2, it seems likely that the cladogenic event that separated the ancestors of $S$. pavo from those of the freshwater blennies took place at least in the Middle Miocene or earlier, well before the Messinian salinity crisis.

Our data suggest that the split of the Moroccan lineage from the remaining freshwater Salaria may have occurred in the Pliocene. However, the upper limit of the credibility interval estimated by BEAST for this split was 4.32 MYA. As we know that our calibration provides only a lower limit, it is not unrealistic to assume that this event may have occurred 5-5.5 MYA during the Messinian Salinity Crisis (e.g., Briggs, 1995). The Messinian provided a narrow time window during which the Mediterranean was partly desiccated and partly occupied by small water bodies. Towards the final stages of the Messinian salinity crisis much of the Mediterranean basin contained water of reduced salinity (the Lago Mare phase, Briggs, 1995). Thus, the Messinian may have provided the roots through which the freshwater Salaria reached both European and African waters and the Middle East.

The samples from Israel and some from Turkey form the second clade to emerge after the splitting of the Moroccan samples. Kosswig (1967) stated that the fish from the Jordan valley are isolated at least since the Pliocene. If this observation is confirmed, it means that our molecular clock is not overestimating the more basal divergences in Salaria. It would also mean that the Moroccan fish may have diverged much earlier, most likely in the Late Miocene, as suggested above.

From a biogeographic perspective it is interesting to note that in Turkey, apart from this old lineage, there are other fish that belong to a very distinct clade which also includes fish from Croatia, Greece and Spain. This observation emphasizes the very interesting position of Turkey and the Middle East, as a whole, as an area of major crossroads of distinct biogeographic influences (Durand et al., 2002; Hrbek and Meyer, 2003).

The present data show a very low divergence between populations from places as far apart as Spain, Croatia, Greece and some fish from Turkey (Fig. 2 and Table 2). Indeed, the divergence times among these samples place their separation well within the Pleistocene. Although the present paper did not support the hypothesis of Perdices et al. (2000) for the entire radiation of the freshwater Salaria, we can not rule out the possibility of some dispersal by sea as $S$. fluviatilis retains the ability to survive and osmoregulate efficiently in seawater for periods of at least three months (Plaut, 1998). This means that the ancestors of some populations could have dispersed via the sea, especially during the glacial periods. Although the freshwater blennies breed and develop in freshwater the larvae are planktonic and only settle at 27-31 days at a temperature of $20-21{ }^{\circ} \mathrm{C}$ (Gil et al., in press). The existence of this planktonic stage would have facilitated the marine dispersal of this fish. Glaciations cause drastic drops in sea level of more than one hundred meters, which caused many rivers to spread in what is now the sea floor (Briggs, 1995; Dias et al., 1997). These hydrographic changes, coupled with temperature drops, which were especially severe in inland waters, may have pushed freshwater Salaria to areas of brackish or marine conditions.

The present paper highlights the need of a detailed taxonomic reassessment of the status of the freshwater populations of Salaria.
The Moroccan samples must have split more than 2 MYA. They are sister to all other freshwater Salaria. Their distinctiveness, both in the mitochondrial and nuclear genes analyzed, argues in favor of the recognition of a new species in Morocco. Salaria economidisi is nested within samples ascribed to S. fluviatilis, which makes the latter species a paraphyletic entity. Kottelat (2004) found that the morphological differences between the fish in Lake Trichonis (now S. economidisi) and other freshwater Salaria were sufficiently large to warrant specific status to that population. Our results show that there are some splits in the freshwater blennies that are of comparable or greater age, namely that of the Moroccan samples and those of Israel. It seems plausible that several, as yet unrecognized, species may be present in the freshwater clade of Salaria. Thus, a general revision of all freshwater members of this genus is needed. This task is of the highest relevance for conservation as many of these populations are threatened in various degrees.

\section{Acknowledgments}

We appreciate the skillful technical assistance provided by S. Chenu. We would like to thank M. Goren for samples of Salaria fluviatilis from Israel and C. Sousa-Santos for help with the edition of some chromatograms. This study was funded by the Pluriannual Program (FCT, UI\&D 331/94, partially FEDER funded). A. Levy was also funded by a Post-Doc grant (SFRH/BPD/41391/ 2007). Collection of specimens complied with the current laws of each country.

\section{Appendix A. Supplementary data}

Supplementary data associated with this article can be found, in the online version, at doi:10.1016/j.ympev.2009.03.029.

\section{References}

Almada, V.C., Oliveira, R.F., Gonçalves, E.J., Almeida, A., Santos, R.S., 2001. Patterns of diversity of the North-Eastern Atlantic Blenniid fish fauna (Pisces: Blenniidae) Global Ecol. Biogeogr. 10, 411-422.

Almada, F., Almada, V., Guillemaud, T., Wirtz, P., 2005. Phylogenetic relationships of the north-eastern Atlantic and Mediterranean blenniids. Biol. J. Linn. Soc. 86, 283-295.

Almada, V.C., Robalo, J.I., Gonçalves, E.J., Levy, A., Patzner, R.A., 2009. Blennies in temperate seas. In: Patzner, R.A., Gonçalves, E., Hastings, P., Kapoor, B.G. (Eds.), The Biology of Blennies. Science Publishers, Enfield, NH, pp. 119-135.

Avise, J.C., 2000. Phylogeography: The History and Formation of Species. Harvard University Press, Cambridge.

Bath, H., 1976. Revision der Blenniini (Pisces: Blenniidae). Senck. biol. 57, 167-234.

Bell, M.A., Foster, S.A. (Eds.), 1994. The Evolutionary Biology of the Threespine Stickleback. Oxford University Press, Oxford.

Bermingham, E., McCafferty, S.S., Martin, A.P., 1997. Fish biogeography and molecular clocks: perspectives from the Panamanian isthmus. In: Kocher, T.D. Stepien, C.A. (Eds.), Molecular Systematics of Fishes. Academic Press, New York, pp. 113-128.

Bock, M., Zander, C.D., 1986. Osteological characters as tool for blenniid taxonomya generic revision of European Blenniidae (Percomorphi; Pisces). Z. Zool. Syst. Evol. forsch. 24, 138-143.

Briggs, J.C., 1995. Global Biogeography. Developments in Palaeontology and Stratigraphy. Elsevier, Amsterdam.

Chow, S., Hazama, K., 1998. Universal PCR primers for S7 ribosomal protein gene introns in fish. Mol. Ecol. 7, 1247-1263.

Dias, J.A., Rodrigues, A., Magalhães, F., 1997. Evolução da linha de costa em Portugal, desde o último máximo glaciário até a actualidade: síntese dos conhecimentos. Estudos do Quaternário 1, 53-66.

Drummond, A.J., Rambaut, A., 2007. BEAST: Bayesian evolutionary analysis by sampling trees. BMC Evol. Biol. 7, 214.

Durand, J.D., Tsigenopoulos, C.S., Ünlü, E., Berrebi, P., 2002. Phylogeny and biogeography of the family Cyprinidae in the Middle East inferred from cytochrome $b$ DNA-evolutionary significance of this region. Mol. Phylogenet. Evol. 22, 91-100.

Farris, J.S., Källersersjö, M., Kluge, A.G., Bult, C., 1985. Testing significance of incongruence. Cladistics 10, 315-319.

Felsenstein, J., 1985. Confidence-limits on phylogenies: an approach using the bootstrap. Evolution 39, 783-791. 
Gil, M.F., Faria, C., Almada, V.C., in press. An efficient technique for the captive breeding of an endangered freshwater fish Salaria fluviatilis (Pisces: Blenniidae), with a description of its ontogeny. J. World Aquacult. Soc.

Hayes, A., Kucera, M., Kellel, N., Sbaffi, L., Rohling, E.J., 2005. Glacial Mediterranean sea surface temperatures based on planktonic foraminiferal assemblages. Quaternary Sci. Rev. 24, 999-1016.

Heymer, A., 1985. Morphologie, coloration, intersexualité et anatomie des organes reproducteurs chez Blennius basiliscus (Teleostei, Blenniidae). Revue Française d'Aquariologie 12, 39-52.

Hrbek, T., Meyer, A., 2003. Closing of the Tethys Sea and the phylogeny of Eurasian killifishes (Cyprinodontiformes: Cyprinodontidae). J. Evol. Biol. 16, 17-36.

Huelsenbeck, J.P., Ronquist, F., 2001. MRBAYES: Bayesian inference of phylogeny. Bioinformatics 17, 754-755.

Kishino, H., Hasegawa, M., 1989. Evaluation of the maximum-likelihood estimate of the evolutionary tree topologies from DNA-sequence data, and the branching order in Hominoidea. J. Mol. Evol. 29, 170-179.

Kosswig, C., 1967. Tethys and its relation to the peri-Mediterranean faunas of freshwater fishes. In: Adams, C.G., Ager, D.V. (Eds.), Aspects of Tethyan Biogeography. Systematics Association Publication, pp. 313-324.

Kottelat, M., 2004. Salaria economidisi, a new species of freshwater fish from Lake Trichonis, Greece, with comments on variation in S. Fluviatilis (Teleostei: Blenniidae). Rev. Suisse Zool. 111, 121-137.

Kottelat, M., Freyhof, J., 2007. Handbook of European Freshwater Fishes. Kottelat, Cornol \& Freyhof, Berlin.

Loncaric, N., Auffret, G.A., Abrantes, F., Baas, J.H., Gaspar, L., Pujol, C., 1998. Late quaternary sedimentation patterns on the Meriadzek Terrace, Bay of Biscay (ESSCAMP 02 core: 47 N 9 W). Mar. Geol. 152, 57-73.

Muss, A., Robertson, D.R., Stepien, C.A., Wirtz, P., Bowen, B.W., 2001. Phylogeography of Ophioblennius: the role of ocean currents and geography in reef fish evolution. Evolution 55 (3), 561-572.

Nelson, J.S., 2006. Fishes of the World. Wiley, New York.

Norman, J.R., 1943. Notes on the blennioid fishes. I. A provisional synopsis of the genera of the family Blenniidae. Ann. Mag. Nat. Hist. 10 (11), 793-812.
Ostellari, L., Bargelloni, L., Penzo, E., Patarnello, P., Patarnello, T., 1996. Optimization of single-strand conformation polymorphism and sequence analysis of the mitochondrial control region in Pagellus bogaraveo (Sparidae, Teleostei): rationalized tools in fish population biology. Anim. Genet. 27, 423-427.

Perdices, A., Doadrio, I., Cote, I.M., Machordom, A., Economidis, P., Reynolds, J.D. 2000. Genetic divergence and origin of Mediterranean populations of the River Blenny Salaria fluviatilis (Teleostei: Blenniidae). Copeia 723, 731.

Plaut, I., 1998. Comparison of salinity tolerance and osmoregulation in two closely related species of blennies from different habitats. Fish Physiol. Biochem. 19, 181-188.

Posada, D., Crandall, K.A., 1998. ModelTest: testing the model of DNA substitution. Bioinformatics 14, 817-818.

Ronquist, F., Huelsenbeck, J.P., 2003. MRBAYES 3: Bayesian phylogenetic inference under mixed models. Bioinformatics 19, 1572-1574.

Saitou, N., Nei, M., 1987. The neighbor-joining method: a new method for reconstructing phylogenetic trees. Mol. Biol. Evol. 4, 406-425.

Shimodaira, H., Hasegawa, M., 1999. Multiple comparisons of log-likelihoods with applications to phylogenetic inference. Mol. Biol. Evol. 16, 1114-1116.

Swofford, D.L., 2003. PAUP*. Phylogenetic Analysis Using Parsimony (* and other methods). Version 4b.10. Sinauer Associates, Sunderland, MA.

Templeton, A.R., 1983. Phylogenetic inference from restriction endonuclease cleavage site maps with particular reference to the evolution of humans and the apes. Evolution 37, 221-224.

Thompson, J.D., Gibson, T.J., Plewniak, F., Jeanmougin, F., Higgins, D.G., 1997. The ClustalX windows interface. Flexible strategies for multiple sequence alignment aided by quality analysis tools. Nucleic Acids Res. 24, 4876-4882.

Westernhagen, H.V., 1983. Observations on the Reproductive and Larval Biology of Blennius pavo (Pisces; Teleostei). Helgolander Meeresun. 36, 323-335.

Zander, C.D., 1972. Evolution of Blennioidei in the Mediterranean Sea. Revue des Travaux de l'Institut des Pêches maritimes 37, 215-221.

Zander, C.D., 1986. Blenniidae. In: Whitehead, P.J.P., Bauchot, M.-L., Hureau, J.-C., Nielsen, J., Tortonese, E. (Eds.), Fishes of the North-eastern Atlantic and the Mediterranean. UNESCO, Paris, pp. 1096-1112. 